\title{
Integrating Declarative and Procedural Knowledge on Grammar through E-Portfolio Assessment
}

\author{
Rukminingsih \\ STKIP PGRI Jombang \\ Rukminingsih19@yahoo.co.id \\ Pryla Rochmawati \\ IAIN PONOROGO \\ pryla@iainponorogo.ac.id \\ Nala Sita Rukmi \\ STKIP PGRI Jombang \\ Nallarukminingsih16@gmail.com
}

\begin{abstract}
This study aims to reveal (1) whether there is significance different students' achievement who are taught grammar through integrating declarative and procedural knowledge by implementing E-Portfolio assessment and (2) the process of integrating declarative and procedural knowledge by implementing E-Portfolio assessment. It employed mixed method of concurrent design. The populations of this research were 120 students of grammar class in English Department of STKIP PGRI Jombang. The number of samples was 40 students for experimental group and 40 students for control group by employing cluster random sampling technique. The data were collected through test and observation and it applied ANCOVA for quantitative data analysis and data display, data reduction and drawing conclusion for qualitative data analysis. The finding showed that (1) there is significant difference on students' grammar understanding between experimental group and control group. (2) E-portfolio through students' blogs gives opportunity to students to engage their efforts, progress, and achievements in given areas and the strategy has the additional benefit of enabling students to publish and share ideas or tasks easily involving authentic audience or their classmates. It implied that assessing by using Electronic Portfolio is positively effective to be implemented in integrating both declarative and procedural knowledge in Grammar course.
\end{abstract}

Keywords: e- portfolio assessment, declarative knowledge, procedural knowledge, grammar.

\section{INTRODUCTION}

In teaching grammar, the disconnect reflects a separation between declarative knowledge and procedural knowledge. According to Johnson (1996), Declarative knowledge is knowledge about something. Declarative knowledge enables a student to describe a rule of grammar and apply it in pattern practice drills. Procedural knowledge is knowledge of how to do something. Procedural knowledge enables a student to apply a rule of grammar in communication. Procedural knowledge does not translate automatically into declarative knowledge; 
many native speakers can use their language clearly and correctly without being able to state the rules of its grammar. Likewise, declarative knowledge does not translate automatically into procedural knowledge; students may be able to state a grammar rule, but consistently fail to apply the rule when speaking or writing. People associate grammar with errors and correctness but knowing about grammar also helps us write sentences and paragraphs in good grammar

To address the declarative knowledge/procedural knowledge dichotomy, teachers and students should apply the strategy which can involve both declarative and procedural knowledge. According to Prabhu (1980), Traditional Grammar Teaching Methods in Iran If we observe the grammar teaching class in middle schools or most of the schools, we may find out that nearly every teacher follows a simple way like this: firstly, the teacher lists the grammar rules. Then, the students learn by heart all the rules and do some exercises. Lastly, the teacher gives more written exercises such as blank-filling or translation.

Grammar courses on English language department at STKIP PGRI Jombang are courses intended to help students communicate in English both orally and written completely in accordance with the rules of grammar in English. Teaching grammar practice is to help students memorize the form, to help students produce the word order, to give intensive practice through repetition, to provide opportunities for feedback and error correction, to give practice in pronouncing new forms, to develop confidence. Production is to reduce control and encourage students to find out what they can do, to encourage students to use the forms in expressing their own content, to help students see the usefulness of what they have learned, to check what has been learned and diagnose problems. It is obviously known to everyone that grammar is an indispensable part of English learning in Iran. In order to get more information about grammar, the teachers try to list as many as possible the rules in each case, and the students have already got used to writing down all the rules on their notebook.

Teachers try their best to give a clear explanation of each item and try to apply more information to the students. Almost every student spends most of their time memorizing rules of grammar in or after class. Correspondingly, grammar class became the dullest class and most students got confused by so many rules. Many teachers or lecturers give the grammar class by using traditional method. They just have their students memorize the rules and then do the exercises. It is also supported by Weaver (1996) which state in the following:

"Our traditional teaching of
grammar has little transfer to
writing situation is underlying
behaviorist learning theory that we
have simply taken for granted the
behaviorist ideas that practice
makes perfects".

To answer the dichotomy of declarative and procedural knowledge, the lecturer should implement strategies that may include both of them. However, many students who still spend their time memorizing grammar patterns either within or outside the classroom, so the grammar class into a drab classroom and many students confused with its many grammar patterns should they memorized. The step that is generally applied in teaching students grammar, namely; lecturer gives the concept of grammar patterns and then students are required to memorize the patterns, and do some exercises; then, the lecturer gives more depth the concept of grammar patterns with some form of exercise in the form of translation sentence patterns. 
According to Bullock and Haw (2005), Organizing the set of students' works into a portfolio of material is to encourage them to have a ready reference of where they can track their own progress and see the extent to which their own abilities, strength, or weaknesses consistent grammar courses. It has been an innovative way to use these skills to create a portfolio which can be implemented in various skills, it is obvious that basic digital competences are important, and more advanced skills may be needed depending on the platform the students choose to use. In this digital era, students can spend a lot of time playing around with things online. Whether it's looking at social media, watching videos, and gaming. In addition, various multimodality in e-Portfolios (audio, image, video) stimulates them more interesting. Moreover, some skills such as writing skills, critical thinking and creativity support the creation of relevant and interesting content (Kunnari, Laurikainen, \& Torseke 2017). The use of $\mathrm{E}$ portfolio in grammar as declarative and procedural knowledge leads the students to challenge them actively to implement the declarative knowledge in a pattern drills and procedural knowledge in writing some paragraphs. The need for teaching grammar through eportfolio can improve both student learning grammar declarative and procedure knowledge. They not only recognize the patterns of sentence structure but also implement the sentence patterns in writing some paragraphs with the appropriate grammar. In teaching grammar with eportfolio, not only provides a picture of what students know and what they can do, how an overview of the development of the students is given during the learning process.

E-Porfolio also provides the impetus for self-reflection, participation and assessment but also encourages them to participate actively in every aspect of learning which includes reaching the goals, selecting instructional materials and having peer assessment. My grammar class is encouraged to use e-portfolios to foster collaborative learning environment where more competent students can provide feedback to peers. When students are given the opportunity to guide others it facilitates peer -to-peer learning and deeper understanding of the lesson. Yatsibas (2013) states that e-portfolio can enhance students' self-assessment skill because they can monitor their learning process, their strength and weakness and help them to take responsibility for their learning results. Nambiar \& Melor (2017) state that the use of other web tool such as blogs, Google document and wiki space should be used an alternative supporting students' reflective practice for learning process.

In teaching grammar, the disconnect between grammar as declarative knowledge and procedural knowledge reflects a separation between declarative knowledge and procedural knowledge. According to Weaver (1996), "Declarative knowledge is knowledge about something." Declarative knowledge enables a student to describe a rule of grammar and apply it in pattern practice drills. However, procedural knowledge is knowledge of how to do something. Its knowledge enables a student to apply a rule of grammar in communication. Procedural knowledge does not translate automatically into declarative knowledge; many native speakers can use their language clearly and correctly without being able to state the rules of its grammar. Likewise, declarative knowledge does not translate automatically into procedural knowledge; students may be able to state a grammar rule, but consistently fail to apply the rule when speaking or writing (Weaver, 1996). In declarative knowledge, Teachers try their best to give a clear explanation of each item and try to apply more information to the students. Almost every student spends 
most of their time memorizing rules of grammar in or after class. Correspondingly, grammar class became the dullest class and most students got confused by so many rules.

Many teachers or lecturers give the grammar class by using traditional method. They just have their students memorize the rules and then do the exercises. Bullock and Hawk (2005) emphasizes that Electronic Portfolios are a creative means of organizing, summarizing, and sharing artifacts, information, and ideas about teaching and/or learning, along with personal and professional growth. The reflective process of portfolio development can be as important as the final product. In many cases, they are used as part of faculty and student evaluation along with other assessment tools such as standardized tests. A portfolio is a sampling of the breadth and depth of a person's work conveying the range of abilities, attitudes, experiences, and achievements. Farrell (2014) states that learning by using eportfolio is able to be developed continuously through reflection because students' e portfolio provides students understand better what they know and do. Students are motivated to engage actively in learning process as they set goals, review goals and self-reflection on their task (Cheng \& Chau, 2013 \& Buzzetto-More, 2010)

An e-portfolio provides as a selective and structured collections of information, gathered for specific purposes, record of one's accomplishments and growth which are stored digitally and supported by appropriate software, developed by using appropriate multimedia and customarily within a web environment and retrieved from a website. In a generic level, electronic portfolios are part of a personal online space with a repository function and an organizing function supporting collaboration and feedback the learning process was examined through a workspace in e-Portfolio, making students' learning more visible both to themselves and to additional audiences such as teachers, peers, parents and the whole school community (Eynon, Gambino, \& Török 2014)

The concept has been known as an ability-based learning or learning by their own style. Little (2009) states "Portfolio to integrate pedagogic abilities, learning and evaluation of all of which support critical thinking and learning autonomy." Moreover, Johnson (2010) argues that some researchers also have found difficulty in managing time and studying the materials due to lack of experience in producing portfolio This shows that-EFL students in developing skills can manage their learning autonomy in grammar as declarative and procedural knowledge. Alexiou and Paraskeva (2013) emphasize that a self-regulated oriented e-portfolio could increase motivation and self-efficacy and could be used for professional and academic development. This makes the students more self-confident, motivated, and engaged in learning (Yastıbaş, 2013). In addition, e-portfolio assessment increased active participation because students had control over the organization, selection, and design of the content of their e-portfolios.

In some cases, the exercise can be successfully completed without the student understand the meaning of the forms they learn. As a result, inwriting or speaking students do not understand how they write or speak correctly so many grammar mistakes are made. Portfolios are applied to the grammar course helps students to adapt a communicative approach which also apply procedural knowledge and declarative knowledge. It means that a student portfolio on grammar courses, students not only learn grammar to the patterns (pattern) but also apply knowledge of sentence grammar they are written "With more and more schools going paperless or migrating to the "cloud" (storing files on the Internet), student work has become more easily shareable, accessible 
by many, and more easily"(Barret, 2010). Baston \& Chen (2008) also emphasizes that implementing E portfolio is an ideal vehicle of academic and professional development of technology which is suitable with digital application. It provides the digital application which enable interaction, collaboration and sharing thus providing users with unprecedented learning experience. Many teachers have turned to digital portfolios -- or "e-portfolios" -- for their students to get more effective teaching strategy.

Reading and writing texts online are basic skills that students need to be literate citizens in the $21^{\text {st }}$ century. Teaching with blogs provides the opportunity to engage students in both of these literacy activities, and the strategy has the additional benefit of enabling students to publish their writing easily and to share their writing with an authentic audience. When students write entries and comment on the entries of their peers, blogs become an integral part of a lively literacy community. "Blogs can be effectively integrated into the "broader professional context" which includes an understanding of learner needs, the educational setting, available resources, syllabus, and teaching learning goals" (McDonough \&

\section{METHOD}

This study employed mixed methods research. This present research combined qualitative and quantitative approaches in a single or multi phased study. This study aims at investigating the integration of declarative and procedural knowledge by implementing electronic portfolio assessment in grammar course by using data quantitative and qualitative. In line with Ary (2010), mix method research aims at seeking corroboration of finding to answer the research problems of this study which investigate the depth of study. Concurrent designs were applied as research design Ary
Shaw, 1993, p.5). Yunus, et. al. (2014) stated that blog can motivate students' writing skills among ESL learners although there may some problems occur and hinders the lecturers to use it because of time consuming to give feedback on students' blogs.

Students can post on such topics as journal/diary entries, reflections on their writing process, details on their research projects, commentary on recent events or readings, and drafts for other writing they are doing in their blog. Once a student posts an entry, others in the class can respond, provide supportive feedback, and offer additional suggestions or perspectives. By writing and commenting on blogs, students write for real readers (not just for their teachers). As a result, students focus on clear communication and get immediate feedback on whether they communicate effectively. Teaching with blogs provides the opportunity to engage students in both of these literacy activities, and the strategy has the additional benefit of enabling students to publish their writing easily and to share their writing with an authentic audience. Ellison \& Wu (2008) state that a blog is a medium in which the students can express their ideas, reflect their experiences and talk to their friends.

(2010) stated that in concurrent design, both qualitative and quantitative data are collected separately but at approximately the same time. Then it is analyzed separately and interpretations are made for each set of data.By obtaining separate collection, analysis, and interpretation phases, then the results are integrated in finding and discussion.

This research was conducted in "STKIP PGRI Jombang", Jombang, East Java, Indonesia. The participants were the fourth semester of English Department of STKIP PGRI Jombang. From the target population, the present study only two 
classes were taken as the samples. The researchers employed 2016 A consisting as control group and 2016 B consisting 40 students. In this study, teaching grammar by implementing a students' E Portfolio to assess integrating declarative and procedural knowledge in grammar course is independent variable since it influences the teaching learning process. The result of the research in the form of the students' grammar achievement as dependent variables. The instrument of the study to collect the data was test. The test is constructed in the form of multiple choices and composing some paragraphs (writing context). In this study the test was divided into pretest and posttest. Pretest was given before treatment. The objective of holding pretest was to know the previous grammar in participle of the students before treatment. And posttest was administrated in order to know the effectiveness of teaching grammar by integrating to writing context on students' grammar achievement after conducting the treatment. In preparing for the test the researcher did the procedure such as (1) developing and constructing test, (2) trying out the planned test validating the test, (3) analyzing the result of try out, (4) validating the test.

In quantitative research design the researcher uses a test consisting pretest and test to reveal the data about the students'

achievement. It is categorized into quasi experimental method to measure whether the students' E-portfolio can apply in grammar class more accurately is more effective than learning Grammar only with English pattern drills. The study employs test as quantitative data collection technique. Those data were analyzed by ANCOVA by using SPSS 19 program for Windows. Furthermore, qualitative data analysis consisting of data reduction, data display, and drawing conclusion. Observations are employed to collect the data as qualitative data to capture the process of how the process of integrating declarative and procedural knowledge is by implementing electronic portfolio in grammar course.

\section{RESULTS AND DISCUSSION}

There are two findings to answer the research questions of this study. First finding is the significance different students' achievement who are taught grammar through integrating declarative and procedural knowledge by implementing EPortfolio. There are some points that explained in data analysis, those are the description analysis of Pre-test score, the description of posttest score and analysis of covariance. The descriptive statistic of learners' pretest both of experimental and control group presented in the table below:

Table 1. Descriptive Statistics of pretest

\begin{tabular}{|cl|r|r|r|}
\hline \multicolumn{2}{|c|}{ Teaching Method } & N & Mean & Std. Deviation \\
\hline Pretest Scores & $\begin{array}{l}\text { integrating declarative and procedural } \\
\text { knowledge by implementing electronic } \\
\text { portfolio assessment in grammar course }\end{array}$ & 40 & 57.75 & 7.005 \\
& Pattern practice drills & 40 & 59.75 & 5.300 \\
\hline
\end{tabular}

The table above showed that the mean score of both experimental and control group are 57.75 and 59.75 respectively. It implied that their background knowledge related to grammar were relatively the same. The following table revealed the descriptive statistic of students' posttest both experimental and control group. 
Table 2. Descriptive Statistics of posttest

\begin{tabular}{|l|r|r|r|}
\hline Teaching Method & Mean & Std. Deviation & \multicolumn{1}{|c|}{ N } \\
\hline $\begin{array}{l}\text { Integrating declarative and procedural knowledge by } \\
\text { implementing electronic portfolio assessment in } \\
\text { grammar course }\end{array}$ & 76.25 & 6.578 & 40 \\
\hline Pattern practice drills & 64.50 & 8.973 & 40 \\
\hline Total; & 7 & 9.801 & 80 \\
\hline
\end{tabular}

The table 2 showed that mean score of experimental groups (in this case integrating declarative and procedural knowledge by implementing electronic portfolio assessment in grammar course) is 76.25 (s.d. $=6.578$ ). The increase of mean score from pretest mean score is 14.23 or $31 \%$ while the mean score of control group (in this case Pattern practice drills) is
64.50 (s.d. $=9.801)$ and the increase of the mean score is 1.46 or $3.6 \%$. The increase of the mean score of integrating declarative and procedural knowledge by implementing electronic portfolio assessment in grammar course is higher than the practice pattern group. In analysis of covariance, it was used pretest and posttest score. The analysis of covariance presented in this table below

Table 3. Tests of Between-Subjects Effects

Dependent Variable: Posttest

\begin{tabular}{|l|r|r|r|r|r|r|}
\hline Source & $\begin{array}{c}\text { Type III Sum of } \\
\text { Squares }\end{array}$ & Df & Mean Square & F & Sig. & $\begin{array}{c}\text { Partial Eta } \\
\text { Squared }\end{array}$ \\
\hline Corrected Model & $3346.544^{\mathrm{a}}$ & 2 & 1673.272 & 30.371 & .000 & .441 \\
Intercept & 4497.897 & 1 & 4497.897 & 81.641 & .000 & .515 \\
Pretest & 585.294 & 1 & 585.294 & 10.624 & .002 & .121 \\
Method & 3024.342 & 1 & 3024.342 & 54.895 & .000 & .416 \\
Error & 4242.206 & 77 & 55.094 & & & \\
Total & 403800.000 & 80 & & & & \\
Corrected Total & 7588.750 & 79 & & & & \\
\hline
\end{tabular}

a. $\mathrm{R}$ Squared $=.441$ (Adjusted R Squared $=.426$ )

Based on the table 3 above, it depicts that the independent variable (in this case teaching method) finds an F-value of the effect of teaching method 3024.342 $(\rho<.000)$ and column labeled Sig the value is .000 where it is less than 0.01 (an alternative alpha level). It means that those two groups differ significantly. Furthermore, F-value of the effect of pretest $10.624(p<.000)$ and the significant value is 0.000 (which actually means less than 0.01). It implied that the covariate is significant. Thus, it can be 
concluded that both the experimental and control groups differed significantly. It means that alternative hypothesis $\left(\mathrm{H}_{\mathrm{a}}\right)$ revealed that integrating declarative and procedural knowledge by implementing electronic portfolio assessment in grammar course better achievement than students who were taught using the practice of English sentence patterns or pattern drills accepted and $\mathrm{H}_{0}$ is rejected.

Second finding is the process of integrating declarative and procedural knowledge by implementing electronic portfolio in grammar course.

Based on the result of observation on the process of integrating declarative and procedural knowledge by implementing electronic portfolio in grammar course. Learning can be done into the following steps:

\section{a. Preparation}

In preparation step, the lesson plan must be designed well including the a) instructional objectives b) the material c) teaching technique d) teaching media e) teaching and learning activities and f) assessment. The lesson plan is different in every meeting, it must be appropriate to the topic discussed.

The result of the first observation reveals that when the topic was about the adjective clause. The teaching technique applied is grammar in pattern drills and communicative ways. The material prepared was about adjective clauses the instructional media used blog as media for E-portfolio. The lecturer Introduced the concept of grammar form, the grammar lecture explains the rule and the concept. Then she had the students submit the students' response on participle as their assignment before

\section{b. Implementing Pre-Activity}

having discussion. The students had to do the instruction from the lecturer written in Blog. The Assessment form applied was on going assessment in writing context as procedural knowledge in grammar.

The result of the second observation reveals that when the topic was about the noun clause. The teaching technique applied is grammar in pattern drills and communicative ways. The material prepared was about adjective clauses the instructional media used blog. The lecturer Introduced the concept of grammar form, the grammar lecture explains the rule and the concept. Then she had the students submit the students' response on participle as their assignment before having discussion. The students had to do the instruction from the lecturer written in Blog. The Assessment form applied was on going assessment in writing context as procedural knowledge in grammar.

The result of the third observation revels that when the topic was about the participial. The teaching technique applied is grammar in pattern drills and communicative ways. The material prepared was about adjective clauses the instructional media used schoolboy. The lecturer introduces the concept of grammar form, the grammar lecture explains the rule and the concept. Then she had the students submit the students' response on participle as their assignment before having discussion. The students had to do the instruction from the lecturer written in Blog. The Assessment form applied was on going assessment in writing context as procedural knowledge in grammar

Pre-activity was dealing with brainstorming activity. The lecturer activated the students' background 
knowledge in accordance with the topic discussed. The students should Activate the lecturer's and the students' blogs then read the lecturer's material in her blog then the lecturer explained stepby-step procedures to do with the students' portfolios in their blog

\section{Whilst-Activity}

Whilst-Activity refers to the main activity. It started by giving the students some exercises of the pattern drills as declarative knowledge in their blog. The students had Compose some paragraphs related to the material in their blog as procedural knowledge. Then Discuss the materials about pattern drills as declarative knowledge. Then the lecturer divided the students into groups, each consisting of 5 students and have each group give comments on other groups' blog. In the blog there were some discussion about the students' opinion in their notes, exercises, and paragraphs with their classmates and their lecturer in their blog. Then she gave feedback on her every student's blog then asked her students to revise their notes, exercises, and paragraphs.

\section{Post-Activity}

The lecturer asks the students to make reinforcement and reflection on the grammar class that day. Based on the observation which has been conducted three times, it can be seen that the students may share or ask something confusing about the lesson to the lecturer and their friends. The lecturer gave score to students' portfolio then she assessed the students' writing by using primary trait score which the lecturer just considers the usage and application on participle. The last step, the lecturer had students to correct or to edit their writing after having the score from the lecturer. Using blog provides great forums for students to practice their grammar in writing context as procedural knowledge. One of the most reason why students use a blog appealing that it is more authentic grammar activities both in pattern drills as declarative knowledge and in writing context as procedural knowledge so a wider reader has access to read posted entries which means students tend to put more effort into their blogs. The lecturelr can provide commentary to give some feedback furthermore the students can give comment, questions and feedback to their other friends'. So, there is an interaction among students and lecturer.

\section{Treatment}

The two -selected groups were taught in different ways. The experimental group was taught grammar by using a student portfolio in communicative approach while as the control group was taught by using pattern practice drills method. Here is the treatment or teaching techniques used in this research. Essential Features in The Teaching Technique of Grammar by implementing a students' E-Portfolio to assess integrating declarative and procedural knowledge in grammar course: 
Teaching Grammar by implementing a students' E Portfolio to assess integrating declarative and procedural knowledge in grammar course (experimental group)

1. Introduce the concept of grammar form, the grammar lecture explains the rule and the concept.

2. Have the students submit the students' response on participle as their assignment before having discussion.

3. Activate the lecturer's and the students' blogs,

4. Read the lecturer's material in her blog

5. Explain step-by-step procedures to do with the students' portfolios in their blog

6. Discuss the materials about pattern drills as declarative knowledge

7. Give the students some exercises of the pattern drills as declarative knowledge in their blog

8. Ask students to compose some paragraphs related to the material in their blog as procedural knowledge

9. Divide the students into groups, each consisting of 5 students and have each group give comments on other groups' blog.

10. Discuss the students' opinion in their notes, exercises, and paragraphs with their classmates and their lecturer in their blog.

11. Give feedback on her every student' $\mathrm{s}$ blog.

12. Ask the students to revise their notes, exercises, and paragraphs

13. Provide score to students' portfolio.

14. Assess their writing by using primary trait score

15. Get students to correct or to edit their writing after having the score from the lecturer.
Teaching grammar in Pattern practice drills (control group)

1. Introduce the concept of grammar form, the grammar lecture explains the rule and the concept.

2. Have the students submit the students' response on participle as their assignment before having discussion.

3. Have the students perform the presentation, discussion, questions, and response on the material, participle.

4. Enables student to describe a rule of grammar and apply it in pattern practice drills.

5. Get the students to do exercises such as room test (multiple choice and fill the blanks)

6. Discuss the students' answer then give feedback and positive wash back.

7. Give the test and the form of exercises related to participle.

8. Assess the students 'achievement in grammar by using multiple choice test, 
Based on the results integrating declarative and procedural knowledge by implementing electronic portfolio assessment in grammar course is a learning model that has strong basic principles such as the principle of active learning, cooperative learning groups and reactive. Learning only occurs when students reflect on their experiences, new regulatory concepts based on their experience, to apply the theory into the communicative learning. E-Portfolios provide an ideal context shapes which monitors direct experience in the assessment and learning process. (Barret, 2010). Baston\& Chen (2008) state that implementing E-portfolio is an ideal vehicle of academic and professional development of technology which is suitable with digital application. It provides the digital application which enable interaction, collaboration and sharing thus providing users with unprecedented learning experience.

The lecturer utilized Blog for integrating declarative and procedural knowledge into Electronic Portfolio Assessment in Grammar Course. It adopts communicative approach as well as integrates both declarative knowledge and procedural knowledge. It means that a student portfolio on grammar courses, the students not only learn the grammar to the patterns but also apply knowledge of sentence grammar they are written. Teaching with blogs provides the opportunity to engage students in both of these literacy activities, and the strategy has the additional benefit of enabling students to publish their notes, opinion, answers of the pattern drills exercises and their paragraphs applying the grammar which they have learned easily and to share their portfolio to their lecturers and their authentic audience.

Using e-portfolio in integrating declarative and procedural knowledge of grammar class as students' progress records provide students' artifact which can be saved digitally and monitored any time, they want to see their learning progress. Yastibas \& Yastibas (2014) state that e-portfolio assessment may provide students with artifact which can be used to assess their progress of learning. They can assess and reflect their work involving their weakness and strength. Students' motivation is increased in learning grammar by using eportfolio as their records of their students' progress. Lou and Blaustein (2014); Yastibas \& Yastibas (2014) Alexiou, A., \& Paraskeva, F. (2013) found that e-portfolio assessment can motivate students learning activities. Teaching needs to keep alive to desire to learn. By implementing blended learning, virtual learning and face to face can stimulate students' $\mathrm{s}$ curiosity and motivation for meaningful experiences (Rukminingsih, 2018).

When the students write entries and comment on the entries of their peers, blogs become an integral part of a lively literacy community. The students can post on such their schemata on the material of the lesson, communicate with their lecturer and friends through the blog, have reflections on their task both declarative and procedural task, Once a student posts an entry, others in the class can respond, provide supportive feedback, and offer additional suggestions or perspectives. (Bullock and Hawk, 2005) emphasizes that "Electronic Portfolios are a creative means of organizing, summarizing, and sharing artifacts, information, and ideas about teaching and/or learning, along with personal and professional growth". The reflective process of portfolio development can be as important as the final product. By writing and commenting on blogs, students write for real readers (not just for their lecturer). As a result, students focus on clear communication and get immediate feedback on whether they communicate effectively. 


\section{CONCLUSION AND SUGGESTION}

This research has shown electronic portfolio assessment is effective in integrating declarative and procedural knowledge in grammar course. At the end of the lessons, students are expected to be able to apply grammar in communicative by integrating declarative and procedural knowledge by implementing e- portfolio assessment as an alternative assessment in grammar course. The students asked to post an entry, others in the class can respond, provide supportive feedback, and offer additional suggestions or perspectives. By writing and commenting on blogs, students write for real readers (not just for their teachers). As a result, students focus on clear communication and get immediate feedback on whether they communicate effectively. Using e-portfolio through students' blog provide larger audience for students' work to have feedback from their peer and lecturer so they can self-improvement after getting the feedback. It was found that students really take a pride in their work on the blog and stimulated to do their best for their impending audience through commenting in the blog.

\section{REFERENCES}

Alexiou, A., \& Paraskeva, F. (2013). Exploiting motivation and self-efficacy through the

implementation of self-regulated oriented e Portfolio. Paper presented at The International Conference on E-Learning in the Workplace, New York, USAber 10 , 2009, from http://proquest.umi.com/pqdweb/ index $=4$.

Barrett, H. (2010). Balancing the Two Faces of ePortfolios. Educação, Formação \& Tecnologias, 3(1), 6-14. Retrieved 2 November 2018 from http://eft.educom.pt/index.php/eft/art icle/viewFile/161/102
Batson, T. \& Chen, L., (2008). NextGeneration e-Portfolio, Academic Impressions.

Bullock and Hawk. 2005. Developing a Teaching Portfolio. Pearson, Merill Prentice Hall.

Blaustein, C., \& Lou, Y. (2014). Electronic portfolios: Motivation, self-regulation, and academic

achievement in secondary schools. In M. Searson \& M. Ochoa (Eds.), Proceedings of Society for Information Technology \& Teacher Education International Conference 2014 (pp. 1734-1742). Chesapeake, VA: AACE.

Buzzetto-More, N.A. (2010). Applications of e-portfolio for value added assessment. The e-

portfolio paradigm: informing, educating, assessing and managing with e-portfolios. (p.225-246).

California: Informing Science Pres. Cheng, G., \& Chau, J. (2013). A study of the effect of the goal orientation on the reflective

ability ofelectronic portfolio users. The Internet and Higher Education, 16, 5156.

Ellison, N. B. \& Wu, Y. (2008). Blogging in the classroom: A preliminary exploration of student attitudes and impact on comprehension. Journal of Educational Multimedia and Hypermedia, 17(1), 99-122. Eynon, B., Gambino, L. M., \& Török, J. (2014). What difference can ePortfolio make? A field report from the connect to learning project. International Journal of ePortfolio, 4, 95-114. Retrieved 1 September 2018 from http://www.theijep.com/pdf/ijep127. pdf 
Farrell, T. S. C (2014). Review of reflective writing for language teachers. Journal of Foreign Language Teaching, 11(2), 358-369. Johnson, R.S., (2010). Developing portfolios in education: A guide to reflection, Inquiry, and assessment (2nd ed.). Thousand Oaks, CA: Sage.

Kunnari, I., Laurikainen, M., \& Torseke, J. (2017). Triggering students to create ePortfolios. In I. Kunnari \& M. Laurikainen (eds.) Students' perspectives in ePortfolios. HAMK Unlimited Journal, 25(4) Retrieved on 19 Sep 2018 from https://unlimited.hamk.fi/ammatilline n-osaaminen-ja-opetus/triggeringstudents-to-create-eportfolios

Nambiar V. G. K. \& Melor Md. Yunus (2017). Reflective practice with e-portfolio. Malaysian

Journal of ELT Research, 13(1), 4354.

Rukminingsih (2018). Integrating Neurodidactics into Blended Learning in Accomodating

Students English Learning in EFL

Setting. Paper presented at the Asian
Conference on Education, The Official conference Proceedings. The International Academic Forum, Tokyo-Japan. Retrieved from www.iafor.org.

Weaver Constance. (1996). Teaching Grammar and Usage. The English Journal Education, vol. 85 no7 Yastibas, A., E. \& Yastibs. G., C. (2014). The use of e-portfolio-based assessment to develop

students' self-regulated learning in English language teaching. Paper presented in International Educational Technology Conference, IETC 2014, 3-5 September 2014, Chicago, IL, USA.

Yunus, M.D., Kiing Tuan J., L. \& Salehi, H. (2014). Using blogs to promote writing skills in ESL

classroom. Recent Advance in Educational Technologies Journal. Retrieved from:

https://www.researchgate.net/publica tion/236946577 


\section{APPENDIX: The Lecturer's blog}

This an example of the lecturer's blog for her students. Then the students can ask or share their opinions in her blog.

\section{RUKMININGSIH}

Senin, 06 Oktober 2017

participle

\section{PARTICIPLE}

\section{PRESENT PARTICIPLE}

The man waiting for the bus is my uncle.

(the man waiting for me is my uncle)

The waiting man is my uncle.

(the man who is waiting is my uncle)

The boiling water is very hot.

(The water which is boiling is very hot)

- Having locked all the doors, she went to bed.

(After she had locked all the doors, she went to bed)

- Shouting loudly, he kicked the ball.

(While he was shouting loudly, he kicked the ball)

- Being ill, Linda didn't go to school.

(Because Linda was ill, she didn't go to school)

- $\quad$ Father watched the children playing in the garden.

(After perception verb, such as, see, listen, observe, watch, feel,

look at, smell, hear followed by Verb ing as present participle)

NOTE :

the conjunctions used for participle are because, as, for, since, after, while, when.

\section{PAST PARTICIPLE}

The injured boy was taken to the hospital.

(the boy who was injured was taken to the hospital)

The boy injured in the car accident was taken to the hospital.

the boy who was injured in the car accident was taken to the hospital)

Annoyed by the loud voice, Rere woke up from his dreaming.

( Because Rere was annoyed by the loud voice, he got up from his dreaming) 
Diposkan oleh rukminingsih lea di 03.1847 komentar:

Kirimkan Ini lewat EmailBlogThis!Berbagi ke TwitterBerbagi ke FacebookBagikan ke Pinterest Posting LamaBeranda

Langganan: Entri (Atom)

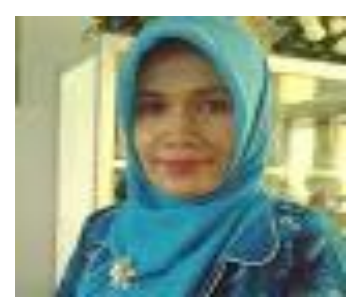

rukminingsih lea

Lihat profil lengkapku

Arsip Blog

- $\boldsymbol{\nabla} 2017(3)$

○ Oktober(3)

- participle

- participle exercises

- LEARNING CONTRACT STRUCTURE IV 
APPENDIX: one of the examples of the student's E-portfolio by using web blog

$\underline{\text { Anita Soraya } 1271225}$

- $\quad$ Argumentative Essay

- Clauses

- Clauses and Phrases

- Complaint letter

- Complex Sentence

- Compound Sentence

- descriptive (paragraph)

- Descriptive paragraph (revise)

- Parallelism

- Participle Exercises

- Persuasive Essay

- Present \& Past Participles (note)

- Report (paragraph)

- Report paragraph (revise)

Jumat, 31 Oktober 2017

Participle Exercises

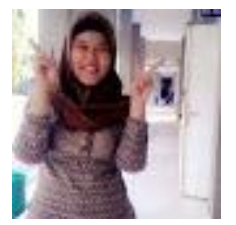

\section{Participle Exercises}

1. The work .computers requires well trained personnel.
a. involved
b. involve
c. involving
d. involves

2. …….... few thousand dollars, he went on a tour to Europe.
a. saved
b. he has saved
c. having saved
d. after he saves.

3. .............her mistakes, the stewardess immediately apologized to the passenger.
a. realized
b. realizes
c. realizing
d. she has realizes

4. Being an outstanding student in our school, he has been offered a scholarship to study in Australia.

The underlined word mean of our school.

a. If he is an outstanding student.

b. Although he is an outstanding student.

c. When he is an outstanding student.

d. As he is an outstanding student.

5. Having sent his letter of application,

a. The company was expected to get a quick reply.

b. Bimo expected a quick reply.

c. A quick reply was expected from the company.

d. They expect the company to send a quick reply.

ANSWERS:

1. C. Involving

2. C. Having saved

3. C. Realizing

4. D. As he is an outstanding student. 
5. B. Bimo expected a quick reply

Diposkan oleh anita soraya di 00.323 komentar:

Kirimkan Ini lewat EmailBlogThis!Berbagi ke TwitterBerbagi ke FacebookBagikan ke Pinterest

Label: Participle Exercises

$\underline{\text { report }}$

\section{Venice}

Venice is a city in northern Italy. It is the capital of region Veneto. Together with Padua, the city is included in the Padua-Venice Metropolitan Area. Venice has been known as the "Queen of the Adriatic", "City of Water", "City of Bridges", and "The City of Light". The city stretches across 117 small islands in the marshy Venetian Lagoon along the Adriatic Sea in northeast Italy.

Venice is world-famous for its canals. It is built on an archipelago of 117 islands formed by about 150 canals in a shallow lagoon. The islands on which the city is built are connected by about 400 bridges. In the old center, the canals serve the function of roads, and every form of transport is on water or on foot.

You can ride gondola there. It is the classical Venetian boat which nowadays is mostly used for tourists, or for weddings, funerals, or other ceremonies. Now, most Venetians travel by motorised waterbuses ("vaporetti") which ply regular routes along the major canals and between the city's islands. The city also has many private boats. The only gondolas still in common use by Venetians are the traghetti, foot passenger ferries crossing the Grand Canal at certain points without bridges.

You can see the amusing city's landmarks such as Piazza San Marco, Palazzo Contarini del Bovolo, Saint Mark's Cathedral or villas of the Veneto. The villas of the Veneto, rural residences for nobles during the Republic, are one of the most interesting aspects of Venetian countryside.

They are surrounded by elegant gardens, suitable for fashionable parties of high society. The city is also well known for its beautiful and romantic view, especially at night.

Diposkan oleh anita soraya di 00.242 komentar:

Kirimkan Ini lewat EmailBlogThis!Berbagi ke TwitterBerbagi ke FacebookBagikan ke Pinterest 
Label: Report (paragraph)

Descriptive

\section{MY HOUSE}

I lived in a small house. It has five rooms: there are two bedrooms, a living room, a bathroom, and a kitchen. Indeed, it is a small house; but I like living in here for wasting my spare time.

When the door is open, I can see the living room. It is so small with only three chairs and a table, nothing else. I prefer reading a novel in this room.

My bedroom is in the left side of the living room. In this room there is a night table next to the bed, a TV, a radio, and a computer. When being bored of reading, I usually play online games, chat with my friends via Facebook and so on.

Next to my bedroom is my mother's. I do not know what is inside because I never come in to see it. In the right side of the living room there is the kitchen. In the kitchen I have everything I need when I get hungry. It is very pleasure when my mother cooks, the smell fills my whole house.

I know it is a very small house, but it is the best place that I have.

Diposkan oleh anita soraya di 00.222 komentar:

Kirimkan Ini lewat EmailBlogThis!Berbagi ke TwitterBerbagi ke FacebookBagikan ke Pinterest Label: descriptive (paragraph) 